\title{
Ambiguity, Authority, and Legitimacy: Reciprocal Echoes among Political Levels in Bangkok
}

\section{Michael Herzfeld}

\begin{abstract}
Thai political life is caught in a tension, sometimes temporally rendered as an oscillation, between extremes of democracy and egalitarianism on the one hand and authoritarian relics of older structures on the other. The confrontation between Red and Yellow Shirts leading up to the 2014 coup might seem to suggest a binary model of Thai political ideology, but the internal complexities of both groups belie a simplistic model of two parties with diametrically opposed views and homogeneous composition. In this article, I argue that it is more productive to approach these tendencies in terms of political performances by politicians representing mutually overlapping and often strikingly convergent ideological tendencies. With the benefit of hindsight, I analyse the 2004 Bangkok gubernatorial election - and in particular one key rally held at Thammasat University ten days before polling day - as a case study in the value of an approach from what I have called 'social poetics' for understanding the dynamics of electoral performance, showing how the relevant social actors play more or less creatively with established norms of electoral conduct.
\end{abstract}

KEYWORDS: Thailand, politics, performance

\section{Performance in Thai Politics}

$\mathrm{T}$ HAI POLITICAL LIFE SEEMS to oscillate between extremes of democracy and egalitarianism on the one hand and authoritarian relics of a supposedly feudal past on the other. The confrontation between Red and Yellow Shirts leading up to the 2014 coup might seem to reduce such confrontations to mere binarism, but I would argue that in fact the internal complexities of both groups belie a simplistic model of two parties with diametrically opposed views and homogeneous composition. It seems both theoretically and descriptively more productive to approach these tendencies in terms of the performance of two models by politicians representing mutually overlapping and often strikingly convergent ideological tendencies. I offer this analysis as a case study in the significance of performative styles for understanding political dynamics, with particular emphasis on the way in which the relevant social actors play more or less creatively with established norms of electoral conduct. In any country, politicians 
must not only offer substantive proposals for much-needed reforms but should do so in a style that implies their capacity for great achievement. Thailand, where self-presentation is a matter of frequent comment and concern but where modesty and self-effacement seem to be in as much demand as aggressive masculinity, is a highly suitable arena for examining how this works in practice.

Both at the grass-roots level and even, more surprisingly, at the most public and elevated level of political leadership and international diplomacy, what sometimes looks like ideological cross-dressing has been far from rare. It is noteworthy, for example, that under former Prime Minister Yingluck Shinawatra, supposedly a populist leader, lèse-majesté prosecutions remained a source of international and internal criticism, while her government's chosen diplomatic representatives made particularly strenuous efforts to promote the monarchy's image abroad. Doubtless some of this had to do with Yingluck's open desire to bring her exiled brother Thaksin Shinawatra - also a former prime minister back home without having to face trial on charges of corruption; a condition for such a move, had it not been derailed by her unsuccessful management of an amnesty initiative, would necessarily have been the suppression of any overt criticism of the monarchy or even covert investigation of its military backers, given the charges of anti-monarchism levelled at Thaksin at the time of his overthrow. But I suggest that such apparently instrumental oscillations also reflect a deeper and older pattern of power management that makes simplistic contrasts between 'authoritarian' and 'democratic' models of governance untenable in the Thai context. Even the accusations of both anti-monarchism and populism levelled against Thaksin are ambiguous at best, given his alleged affection for the often-criticised crown prince, Vajiralongkorn.

The simple binary model is further vitiated by the difficulty it poses of using as the instrument of analysis a rhetoric that is itself part of the problem. In other words, the language of such oppositions as 'democracy-dictatorship', like that of 'red' and 'yellow', is a rhetoric deployed by various political actors for clearly instrumental ends. If we recall that the Democracy Monument on Rajadamnoen Avenue was co-opted by the military after the constitutional coup of 1932 that ended the absolute monarchy, the idea of a People's Alliance for Democracy that would severely limit the electorate's role in determining the membership of future parliaments - it called for a majority (70 per cent) to be appointed by the palace and the military - seems to rest on a precedent, however contradictory in appearance, that was arguably formative in Thai political rhetoric. The language of democracy (and, by extension, of authority) can cover a multitude of sins. ${ }^{1}$ Similar paradoxes have been noted for the opposing side, especially in

\footnotetext{
${ }^{1}$ Comparison with other political systems shows that such manipulation of the rhetoric of democracy is far from rare. The fascist military junta that in various compositions ruled Greece between 1967 and 1974, for example, and that was brought down in part by a student movement (the 'Polytechnic Uprising') that imitated the tactics of the Thammasat revolt of 1973, frequently invoked the
} 
the authoritarian populism, patronage-based networking, and adroit manipulation of the language of transparency that characterised the premiership of Thaksin Shinawatra (Askew 2008; Connors 2003; McCargo 2005; Morris 2004), although some of the Red Shirt supporters have rejected the personality cult that Thaksin was accused of cultivating.

In short, both sides represent both tendencies in fluid mixtures that render them mutually comprehensible. To anticipate some of the burden of this article, I should remark that in some communities 'reds' and 'yellows' seemed to coexist quite easily before the coup, although they were warily attentive to the possibility of a rift if external forces drove them to it. The two sides shared a good deal of common symbolism and both were, in practice, sites of both egalitarian participation and highly authoritarian leadership and structure.

Thai political performance reflects this inner tension, and it does so at many different levels. I have elsewhere discussed how that tension plays out in the micro-politics and internal bureaucracy of a small community in Bangkok, the 300-strong "urban village" of Pom Mahakan on Rajadamnoen Avenue (Herzfeld 2012). Essentially I argued that the leadership in this politically pressured community (for well over two decades it has been fending off the Bangkok Metropolitan Administration's attempts to evict it from its present site, a designated historic monument in the heart of the old dynastic core known as Rattanakosin Island) reflected the difficulties and challenges of achieving democracy in Thailand. In Thai society, strongly egalitarian impulses vie with equally powerful remnants of a bureaucratic hierarchy now transmuted into economic class relations and represented in local communities by a categorical distinction between an oligarchy of supposedly natural 'leaders' (phuи nam) and a majority of outwardly acquiescent 'followers' (phun taam).

That distinction is of widespread significance throughout the country. Local political leaders tend not to share information with their followers; consultation was rare in the past (Rabibhadana 1994: 148-152; Sopon 1992:104-105) and in many cases remains so - not always because the leaders refuse to try to engage their followers, but because the very distinction between followers and leaders is what allows followers the ease of choosing one identifiable faction over another. I am not advocating such hierarchical relations as a necessary prelude to democracy, but simply suggesting that in Thailand democratic politics are widely felt to require the emergence of strong leaders - and that this tendency is strengthened by the habit of national politicians of relying on powerful local leaders to secure blocs of votes, much as in southern Europe politicians would

term 'red fascism' to describe communism, while insisting - in a nationalistic grab for philological legitimacy - that as guardians of the Greek-derived word 'democracy' the colonels were protecting a national heritage as well as a principle of Western governance. Writing of another, current arena, Muehlebach (2009) suggests that the mutual entailment of leftist and neoliberal discourses favors the neoliberal assault on social security. 
woo families or clans for the same purpose (and would be similarly derided for their cynical pursuit of votes with bribes and insincere promises).

Recognition of this dynamic allows us to address the question of how, in a hierarchical society in which nevertheless there are strong claims about democracy and equality, models generated at different social levels resonate so strikingly with each other. Prototypes include idealised notions of the monarch as both a generous and caring patron on the one hand and a just but harsh warrior on the other, and extend both to crypto-colonial images of Western authority and powerful and socially recognisable images of the brawling bandit or powerhungry mafioso, the slum-dweller, the popular entertainer, the self-denying monk, and the working woman. Such models not only inform the micro-politics of everyday life in the capital but are also reflected at the national level in poses struck by political and other leaders. Attention to these stereotypes and their practical deployment allows us to escape Eurocentric assumptions about the impossibility - indeed, the apparent paradox - of the coexistence, well documented in recent years, of enormous wealth and power framed in an old idiom of feudalism on the one hand and the pose of democratic participation on the other. Because of such boldly drawn contrasts and tensions, the peculiarities of the Thai situation suggest a more general theoretical framework for critically connecting political leadership in local communities with the self-presentation of major national figures.

While the distinction between leaders and followers does highlight the agency of a few individuals, it has the paradoxical effect of producing a society where, at every level of political incorporation, collective participation is achieved through a mixture of cajoling and condescension by the leadership group. In the case of Pom Mahakan, I have also suggested that leadership itself has a curiously collective character, with the different styles of individual leaders producing a collective flexibility that maintains both the autonomous character of the community as a whole and the mutual reliance that characterizes the community's internal dynamics, and does so with a striking degree of seamlessness in everyday practice.

Political leaders are in any case representatives of larger groups and interests, and so often retain some degree of charisma, or at least the attributed authority of leadership, even when they fail. The Democrat Party's Abhisit Vejjajiva, for example, was not allowed to step down from the party leadership after the opposition's victory in the elections of July 2011. While there were many reasons for this, including (it might be argued) a sense that it was better to keep a scapegoat at the helm as long as the party had no chance of returning to power through a straightforward election, the qualities that alienated the electorate - his elegant but 'foreign' manners and his willingness to rely on the power of the military to repress revolt - did nothing to undermine his standing as a political leader among those elements of his party who had cast their lot with him and thus arguably would have lost the most through his removal from the scene. 
Such patterns are identifiable in reverse as well. The late Samak Sundaravej, former governor of Bangkok and as such the sworn enemy (as it happens) of Pom Mahakan, and then prime minister in what was widely interpreted as a proxy role representing Thaksin, claimed the egalitarian mantle of the Red Shirts, yet his hectoring manner and his often quite peremptory decision-making evoked more of the aura of the tough warrior than of the negotiator and compromiser, and he was certainly an ardent royalist in all his public pronouncements. One can see similar paradoxes in virtually all areas of political action in Thailand, and these paradoxes became increasingly visible as a result of the street protests and the strikingly negotiated dynamic in which a militarily and royally backed 'democratic' party vied with a 'populist' party that mobilised its forces through an almost military command structure (Ockey 2004), and through which parallel networking marked the organisational practices of those respectively viewed as royalists and populists (McCargo 2005, 2006). One possible effect of such political shadow boxing was the elevation to power of the fallen Thaksin's sister Yingluck, perhaps as an unwilling or even unwitting pawn in the hands of a party establishment that temporarily defused opposition by allowing someone who looked at first like a mere figurehead to take prime-ministerial office. She subsequently emerged as a more forceful and therefore more polarising figure, leaning too heavily to one side of the political divide; the 2014 coup suggests that she especially erred in agitating for an amnesty for her brother, and that this inevitably triggered the street protests that led to the coup. It is clear that mutually opposed factions in Thai politics, ostensibly representing diametrically contrasted social ideologies, are in fact inextricably bound up with each other's trajectories of power, but it is equally clear that those who explicitly act to force the contrast into the open do so at their peril.

In this article, I want to trace these tendencies to a somewhat earlier moment, before the emergence of the colour-coded shirt-wearers, taking a necessarily somewhat abbreviated look at the 2004 gubernatorial election in Bangkok in order to show how performance styles can influence outcomes. These styles also create expectations that often remain unsatisfied, thereby creating new tensions for the future - tensions, in fact, that we can see very clearly in the recent confrontations on the streets and the current military imposition of a pause on political action and of what is effectively a gag on academic critique. Political performance is usually geared more to immediate personal success than to lasting constitutional change, and individual success may - as one might plausibly argue about Thaksin's career - presage disastrous collective evolutions or festering discontent. But of the centrality of performance to achieving political prominence in the first place, there can be little doubt.

In arguing for this approach, I take my lead from Marc Askew’s (2008) timely focus on the role of self-performance in southern Thai politics, particularly in the Democrat Party. Askew in turn works out of a tradition of focusing on language, rhetoric, and symbolism as constitutive (rather than merely reflective) of political 
realities, and his work is suggestive in pointing up the repertoire of 'ideal types' to which, in practice, many Thai politicians allude even as they tweak and tease these models into something more in harmony with their personal goals. I have elsewhere (Herzfeld 1985, 2005) adopted the term "social poetics" for the analysis of such creative social play with form. The essence of a social poetics is not only the evocation of larger or more inclusive levels of imagery what Askew (2008: 287) calls "the active performative delivery of rhetoric and the powerful evocation of social-cultural metaphors that are central to political identification and the symbolic construction of political community" - but also an ability to draw attention to one's mastery of such stylistic skills by creatively deforming their conventions.

Such deformation is the achievement of 'flair' - the disciplined persona showing how far it can go and how well it understands and actively teases the limits of such inventiveness. In a country like Thailand, where what Peter Jackson (2004) has called "the regime of images" aligns a monarchical structure to European-derived notions of bourgeois respectability and where theatrical performance easily spills over into political self-presentation (much as it also does in Italy), such stylistic manipulations are peculiarly accessible. Some of this is helpfully presaged in Ockey's (2004) analysis of Thai political stereotypes and their role in the emergence of a democratic sensibility, but the technical aspects of how to analyse the use of these stereotypes in political practice emerge most forcefully in Askew's recent work.

Askew's analysis is pertinent here for two reasons. First, he focuses intensively on a single political party (the Democrat Party) in its southern stronghold, thereby allowing us to see a controlled range of acceptable behaviours and their enlargement in political performance. While that approach does not directly engage the paradoxes I am describing here directly, it does suggest that they are nascent even within a single political party; and some of his examples show that already at that early date, in the tumultuous years of Thaksin's premiership and immediately beforehand, they generated striking stylistic similarities between two outwardly mutually incompatible political ideologies. Second, and perhaps more important, Askew relates the content of political speeches to styles of dress, gesture, and ironic allusion. For example, his description of the performance of Democrat Party politician Trairong Suwankhiri, later to be a deputy prime minister under Thaksin's arch-enemy Abhisit Vejjajiva, as both a southerner by speech and yet also contemptuous (through ironic imitation) of Thaksin's supposedly peasant-style speech (note here the have-my-cake-andeat-it-too combination of populism and snobbery), shows how such deft jibes invoke thicker clusters of associations than the most elegantly argued defence of policy (nayobai) or ideology (udomkaan) (Askew 2008: 99; see also pp. 195, 224-228, etc.), as did the deliberate evocation of southern Thai puppet theatre. Claiming that his ideological steadfastness and political honesty were rooted in local values might have been a risky undertaking had he done it in words; 
relying on style to convey the implication also creates, in a strictly performative sense, complicity between the politician and his audience, and an appeal to working-class localism that is also a claim to patriotic solidarity - the specific arena in which party leader Abhisit is widely felt to have failed.

Obviously one of the most brilliant examples of self-performance in this idiom is that of the controversial Thaksin Shinawatra himself. While Democrat Party leader Abhisit is often derided as insufficiently 'Thai' because of his nearperfect U.K. English and his Etonian manners and style, Thaksin - ironically a man who takes great pride in his Chinese origins - seemed to embody a certain kind of tough leadership that Thais assimilate to their notions of quintessentially Thai masculinity, and perhaps most dramatically and consistently highlighted by the aggressive anti-intellectualism of his attacks on academics (especially on his arch-enemy the anthropologist and cultural analyst Thirayuth Boonmee) even as he developed his economistic model of "knowledge centres" for the national good. His campaign for 'transparency' was marked by an equally paradoxical - and, for a while, effective - deployment of that rallying cry to disguise the corruption of which even many of his supporters suspected him (Morris 2004).

Because of the Thai predilection for images or what Erving Goffman (1959) famously called "impression management," elections provide an excellent opportunity to assess the links between political values and the idioms of performance. There is little point in speculating about the intentions that underlay the performances themselves - although, to be sure, they clearly represented attempts to convince the electorate of the politicians' excellent motives. Their significance lies, rather, in the assumptions they displayed about the electorate's preoccupations and desires. By narrowing the focus to the Bangkok gubernatorial campaign of 2004, which also gives us some of the advantages of hindsight, and by focusing on only a handful of the contenders, I therefore adapt Askew's analytical stance to a slightly different purpose.

Askew analyses the ways in which a particular party's candidates perform the message that they are honest, decent, and "bandits" of a locally recognisable and "culturally intimate" kind (Askew 2008: 305). But some of these stereotypes cut across party lines, and are as relevant to the capital as they are to the southern provinces. This is particularly important inasmuch as the standoff that led to the 2014 coup is commonly, and to a large extent correctly, interpreted as a class conflict between a rapidly 'bourgeoisifying' capital and a disaffected countryside (especially in the more poverty-stricken areas of the northeast). Just as bourgeois Bangkokians may affect to eat northeastern food with their hands in Isaan-style restaurants, thereby laying symbolic and embodied claim to a nostalgically reclaimed heart of quintessential Thainess while also treating it with all the condescension that 'going native' suggests, their politicians may invoke both the diamond-in-the-rough images that Askew identifies in their southern campaigns and the high-end etiquette of a newly self-confident upper middle class with its 
polite formulae and soft diction. Here, in fact, we are dealing with a situation where the old association with tough southern phuak politics has given way, in the behaviour of some leading politicians, to a more bourgeois sensibility that appeals to older models of kingship and aristocratic reserve - models that conspicuously failed in the south, as Askew notes, and that ultimately denied Abhisit the satisfaction of winning an election outright - his enemies criticised him for agreeing to take and maintain power with the help of the military when he could not point to a single electoral victory such as might have lent legitimacy to such an undemocratic mode of access to power.

\section{The 2004 Bangkok Election}

In the 2004 Bangkok gubernatorial election there was little identification of individual candidates with specific parties. The eventual winner, Apirak Kosayodhin, was unambiguously endorsed by the Democrat Party, of which he was a prominent member, and this did occasion some concern that he might find it difficult to distance himself from the party leader. ${ }^{2}$ By contrast,the original front-runner, Pavina Hongsakul, although eventually supported by Thaksin, did not run as a party candidate and indeed made an issue of that fact. Others simply ran on the basis of their reputations, past achievements, and stated policies; many of the policies cut across the usual ideological and party-political lines.

\section{Chuwit Kamolvisit: The 'Massage Parlour King'}

Foreign observers are often amazed at the kind of people who arrive at high status in the Thai political world. An obvious case in point is Chuwit Kamolvisit, the former 'massage parlour king' who by 2004 had become an unpredictable, often entertaining, but also arguably destabilising element in Bangkok political dynamics. ${ }^{3}$ His massage parlours skirted the edges of legality; their use as sites of prostitution exposed him to legal pressures, which he allegedly resisted by paying enormous bribes to key police officers. In 2003 he was arrested for having illegally tried to evict tenants from an area he wished to develop as high-yield real estate. At this point, one might have thought him finished; but he then published the names of police officers who, he claimed, had accepted his bribes and failed to prosecute him for illegalities that included the furthering of prostitution. As a result, several prominent officers were demoted or otherwise punished, and Chuwit began his rise to political prominence with an unexpectedly strong showing in the 2004 gubernatorial election in Bangkok. As the candidate who finished third, presenting himself as both tough and street-wise on the one

\footnotetext{
${ }^{2}$ See especially the article in the newspaper Khao Sod, 28 June, 2004, p. 38.

${ }^{3}$ For an account of Chuwit's political career, see the brief but useful Southeast Asia Globe article at http://sea-globe.com/sailing-tide-chuwit-kamolvisit-southeast-asia-globe/ (accessed on 16 August 2014).
} 
hand and injured by a heartless state power and his enemies on the other, he exuded a surprising dose of charisma during the race, and this served him well in his subsequent rise to political prominence. In a way he exemplified the term often misleadingly translated as "mafioso" in the Thai context, phuu mii itthiphon, "a person who has influence." By defying the pinched noses of his opponents, especially of those who represented more obviously well-established money, and especially by turning the tables on his alleged persecutors in the police, he played a game not unlike Thaksin's inversion of 'transparency', and at the same time reminded people that in poorer communities tough underworld types often achieved remarkably high status. He also attracted a considerable protest vote against the established political alignments.

Having demonstrated that a tough, masculine performance could win a person of dubious morality considerable support as someone who could get things done despite what he portrayed as unjust police persecution and calumny against his person, he was able to parlay his legal difficulties into a successful bid for the lower House the following year. From haunted victim he rapidly evolved into a highly visible political presence, and his performance in the 2004 election showed just how far he was able to move in a very short time. Aligned against (among others) two former police officers one of whom was widely held to have wielded corrupt power over his clientele (and who later would hold a ministerial office in the Yingluck administration), he was able to present himself as the honest entrepreneur whose skirmishes with bureaucratic legality made him a sympathetic figure for the many Thais who felt themselves to have suffered at the hands of the bureaucracy and the police - and this, despite the fact that the most significant crime of which he was accused involved evicting a large number of poor people from a property he was proposing to develop for his own enrichment. In short, he came across as a man who could get things done, and whom it would therefore be best to have as one's advocate rather than as an enemy.

That self-projection was brilliantly in evidence at the rally at which most of the twenty-two candidates presented their platforms, held at Thammasat University some ten days before the election itself (which was held on 30 August). ${ }^{4}$ The contenders were grouped together according to their availability during the lengthy proceedings; they were invited to present their platforms (nicely summarised also in a Bangkok Post presentation ${ }^{5}$ ) and then subjected to questions from audience members who had managed to secure slots for themselves in front of the main platform. Because it was raining hard outside, what was originally planned as an open-air debate in a space that symbolised the university's role

\footnotetext{
${ }^{4}$ At first it seemed as though there might be as many as thirty candidates. See http://www. nationmultimedia.com/headlines/2004-GOVERNOR-ELECTION-The-Bangkok-dilemma103029.html (accessed on 16 August 2014).

${ }^{5}$ http://www.bangkokpost.com/bkkgov2004/candidates.html (accessed 15 May 2012, but no longer available online).
} 
in fostering democratic aspirations was moved to an indoor location, which had the advantage of making the speeches highly audible. I was able to film a large part of the proceedings, and base some of this analysis on those recordings.

Visually and rhetorically, the debates were decorous enough. But Chuwit Kamolvisit, the 'massage parlour king', had his supporters bring in large numbers of mounted posters, so that his portrait dominated the hall and seemed to echo his words as he spoke. Others relied instead on projecting a serious, technocratic, or simply respectably bourgeois and perhaps academic mien. The audience was mostly quiet, laughing occasionally at a joke and even more rarely breaking out into restrained applause.

The issues that confronted the candidates were simple enough, and relatively few in number. The most important, apparently, was that of the infamous Bangkok traffic jams. Another was the question of what to do with communities occupying sites of historic interest and demanding support for the difficulties associated with maintenance and conservation. A theme that was common to all, as much in its vagueness as in its utopianism, was the goal of active citizen participation (kaansuanruam). This focus invoked what I take to be the key expression of that convergence of democracy and autocracy in Thai politics to which, in different ways, Ockey (2004) and Connors (2003) (with his intriguing and perhaps revealingly awkward formulation of "democrasubjection") have already both drawn attention - the apostrophising of the electorate as a combination of the elder and younger siblings (phii nawng) of the candidate. That rhetoric, as I have argued elsewhere (Herzfeld 2012), is reproduced at the level of local community politics as well, and resonates with the reluctance of ordinary people ( $p r a-$ chaachon) to express their opinions in public even as they demand a voice for themselves.

\section{Rhetorical Skills and Failures: Apirak Kosayodhin, Bhichit Rattakul, and Wutthiphong Phriapchariawat}

Rhetoric, indeed, was not only in plentiful supply; it was also partly constitutive of the outcome, albeit in a context where Democrat Party support for Apirak Kosayodhin - who coincidentally drew the number "1" for his candidacy made a crucial difference in the closing days of the campaign. There can be no doubt that the massive party machine - which, as in the South (Askew 2004), gained considerable ground by relentlessly seeking out cases of vote-buying by its opponents, with the result that such activities became a liability rather than an advantage - was instead a positive factor in the 2004 Bangkok election. But rhetoric also played an important part. In a campaign where only one serious candidate - Chuwit Kamolvisit - deployed an underworld image to his advantage to come in third, the incantatory insistence of virtually all the candidates, Chuwit included, on emphasising the role they planned to give ordinary people in running the city made them highly comparable, and the greater skill of some of them (again, notably Chuwit) at shaping the shared rhetoric with flourishes 
of real mastery boosted those candidates' reputations and enhanced the size of their followings.

Rhetoric had little to do with records of achievement and was directed more toward the promise of better things to come. One former governor, Bhichit Rattakul, had enjoyed a fair degree of popularity, and certainly seemed to display a detailed understanding of the practical problems facing the city. In particular, he addressed the question of the perennial traffic jams in a rather unemotional, technocratic idiom. That, however, may have been his undoing. Since his previous stint as governor had been a period of sudden traffic expansion, his display of confidence may have struck a jarring note. In the end, he fared quite badly in the election, and was reported to have looked for solace to his father, a veteran party politician - hardly a display of self-confidence in the larger sense.

But Bhichit's greatest defect in the electorate's eyes was probably the sense of déjà vu that he evoked. Even claims to being born and bred in the city streets did not excite deep loyalties; the campaign brochure of another candidate, Wutthiphong Phriapchariawat, which was largely devoted to "strategies" (yutthasaat) for improving the city, aimed to humanise the bespectacled and earnest candidate by first noting that he had been born and bred in the old quarter of Banglamphu and then by mentioning how he gone swimming in the local canal and the Chao Phraya river and had cycled around the old royal ground (Sanam Luang) with his "elders and juniors". ${ }^{6}$ In this election, clearly, novelty was an advantage, and the three most successful candidates exploited it. Apirak, by contrast with his fellow-Democrat Party member Bhichit, and the official candidate of his party, brought a unique combination of business experience and social activism to the table; Pavina was a woman with a cause (or, rather, several causes); and Chuwit was a massage parlour tycoon. Chuwit's speeches at the Thammasat meeting were indicative of his nascent political skills. One of the only two candidates sporting facial hair - in his case a hairline moustache that suggested the underworld tough that many assumed him to be - he used much the same rhetoric as the others in emphasising participation and engagement. But there were two key differences. One was his capacity to draw laughs from his audience, sometimes at his own expense (a real winner in Thai social interaction) but often implicitly at that of his rivals. Listeners sensed that they would enjoy listening to him as Governor. The other difference lay in a pacing of his words that demanded attention and, because it used a great deal of sudden acceleration, did not appear to hang heavily in the air even when he repeated himself. What he actually said was not radically different from the speeches of most of the others, but the manner of his delivery reminded people that he was someone who knew how to manage his affairs and control his own public persona.

${ }^{6}$ Phii phi nawng nawng - note the (doubtless intentional) resonance between the image of playmates and the appeal to the electorate, both represented as siblings. 


\section{Pirapong Thanompongphan: The Monotonous Technocrat}

It is instructive to contrast the lively performance of Chuwit Kamolvisit with the speech of another candidate, Pirapong Thanompongphan. Pirapong was an earnest speaker, but with a monotonous, droning, and tediously earnest delivery that drew far more yawns than plaudits from the audience and eventually earned him the organisers' embarrassing plea for a speedy end to his rambling speech. Pirapong's speech was specific about all the wrong things. Rather than showing that he had answers to problems, which both the entrepreneur Apirak and the tough guy Chuwit were able to claim, he spoke at enormous length about all the people he would invite the first day after being elected, enumerating the number of parliamentary deputies, town councillors, and so on who would be invited to listen to the prachaachon: "So, on the $31^{\text {st }}$ [August, the day after the election], I will invite the people, the presidents of the communities, the community committees, to come and hold a conversation....I'll invite the representatives of the people who are interested in the key problems of Bangkok, to come and listen...".

The problem with Pirapong's speech was not that the language was inappropriate, but that it was too monotonously appropriate. The rhetoric of participation has been a long-standing staple of Thai political speechmaking. Pirapong's earnest sincerity did not impress, because it was, in a very real sense, far too ordinary a performance, and there were no details of the kind that would have made people believe that he was going to act any differently from anyone else. In addition, rather than saying what he would do, he talked mostly about how he would talk. In other words, his speech short-circuited itself; it was all too easy to imagine interminable discussions that would no doubt be redolent of good intentions but that would, in all probability, not resolve anything of practical significance at all. It was only when he finally began to offer an example of how the talking strategy he was proposing would benefit the inhabitants of the city that he seemed to be developing a specific policy. Unfortunately for him, it was also at this point that an impatient organiser asked him to wind up his address and he suddenly became agitated because he did, after all, have an example to present - the probable impact of the discussions he envisaged on more effective ways of coping with the effects of Bangkok's perennial flooding.

\section{Apirak Kosayodhin: The Poetics of Competence}

This is not to say that the eventually successful Democrat Party candidate, Apirak Kosayodhin, was rhetorically exciting. On the contrary, he had mastered the art of low-key delivery. There were, however, two key differences that distinguished him from virtually all the other candidates and made his delivery so much more compelling than theirs. The first was that his delivery seemed more deliberately low-key; he used far fewer repetitions, and thus seemed far less anxious 
about getting his message across. The result was that he did, in fact, get that message across quite effectively; he seemed more in charge, and also more confident of his own intentions. The other difference, concomitantly, was a fairly high level of specificity in what he proposed. Notably on the vexed question of how to organise the historic Old Town of Bangkok (Rattanakosin), where some had invoked the law and claimed that they were going to enforce it, Apirak carefully compromised: he supported the idea of a historic zone, he said, but not at the expense of the populations living there. He preferred schemes that allowed residents an actively participatory role, and he spelled out how this would work - not by just talking, he suggested, but by taking charge of local resources. Emphasising each such point with a didactic forefinger (albeit one draped in a bandage as a result of some minor accident), he avoided fiery rhetoric, but managed through an almost exaggeratedly quiet delivery - which was nonetheless more emphatic than Pirapong's - to suggest a confident command of the specific issues and a recognition that any 'solution' to the Rattanakosin Island problem would have to involve the active participation of the residents.

His message was thus not radically different from Pirapong's much vaguer promise of "power [that is] close to the communities" (amnaat klai chumchon), except - and this was a crucial difference, as it turned out - in that he hinted that he would actively refuse to countenance any action that disrupted community life. When the president of Pom Mahakan rose to question him, he repeated this declaration, insisting that the problems of the old city could be resolved without disrupting its social fabric. Whether what he proposed was genuinely more specific is rather doubtful, but he was significantly better at performing specificity - at making people feel that he had the details under control.

His demeanour of quiet efficiency and mastery remained with him after the election. During a surprise visit to Pom Mahakan, he listened with great humility to the residents gathered for the occasion, refusing the noisy privilege of a microphone and seated on a low stool that placed him quite literally on a level with the poor residents of the community. His delivery during the election suggested continuity with precisely that kind of approach once he had won the election; and, while Pirapong's message was in some respects very similar to Apirak's and Pirapong had also declared his intention of "collecting data" before proceeding to any kind of action, it was Apirak who cited data already gathered and known to suggest that his decisions would specifically be designed to protect communities already in existence. While some wealthier Bangkokians probably voted for him more because of his plans for the transportation system and because they feared a Thaksin-supported victory by Pavina Hongsakul (Bangkokians were to vote heavily for Thaksin's Thai Rak Thai party in national elections the following year), some poorer communities, at least, became increasingly hopeful that an Apirak victory would buy them time - a crucial dimension of their own survival strategies. 


\section{Pavina Hongsakul: A 'Perlocutionary Failure'}

Offering help to the poor can, of course, take many forms. There were only two women in the race. One of them, Leena Jangjanya, was disqualified at a relatively late stage; while her antics occasioned some amusement, and might have garnered her votes much as Chuwit's did, she was never considered a serious contender. More surprisingly, perhaps, Pavina Hongsakul, who started out as the pollsters' favourite, mistook her audience very badly and, as a result, misperformed her role, in a stunning illustration of what Austin (1975) would have called "perlocutionary failure". The supposed favourite of Thaksin's Thai Rak Thai party, she went into the election with clear expectations of winning (although it is also true that she had failed to do so in 2000). There were several reasons for her self-confidence. She enjoyed a considerable reputation as an activist for women's and orphans' rights and poor people more generally; she cut an attractive and elegant figure without appearing snobbish or aristocratic; and she admitted to no party-political affiliation. This last feature, which she shared with all but one of the other candidates, was an advantage only in the sense that it did not make her seem to have an unfair advantage in a field dominated by men. As the Democrats' candidate Apirak Kosayodhin began to look increasingly like a serious threat to her chances, however, the Thai Rak Thai activists increasingly endorsed her campaign, and for a while it seemed that her association with the party of the national government offered hope of a way out from the impasses repeatedly generated between municipal and national authorities. But that support was indirect - she remained officially a non-party candidate - and it visibly waned in the closing days of the campaign. After her defeat, she bitterly denounced the party's failure to endorse her outright as the real cause of her failure, and it may indeed have weakened her position when the Democrats' candidate began to draw close. My own hunch, and it cannot be more than that, is that Thai Rak Thai began to desert her when the party leadership realised that she was not likely to win, and that her failure could therefore be construed as an embarrassment to their own party.

Whatever the justice of her charges, it is in any case likely that her own mistakes were the proximate causes of her defeat. She made several tactical errors in the performance of her role as candidate. One was, quite simply, to rely too much on her reputation as an advocate of the poor. She refused to show up with the other candidates at the widely publicised and reported meeting at Thammasat University, making it look as though she considered herself as being above the fray. Perhaps, too, she relied too heavily and too obviously on her reputation as an advocate for women and children, especially among the poor. As Aulino (2012: 77) has recently argued, a suspicion that often attaches to NGO activists is that they are more interested in the karmic interest their performance can garner in terms of merit (bun) than in the plight of those they supposedly help. If that suspicion handicapped Pavina, it was further enhanced from her 
own side - specifically, by Thaksin's relentless attacks on NGOs, which helped raise awareness that some of them were less innocent of venal intentions than their rhetoric suggested. Moreover, such criticisms are consistent with an even older tradition of deriding claims to be "helping" ordinary people (Nelson 1998: 169): better to be a bandit (nakleng), as both Askew and Nelson show in quite different contexts, than an obvious hypocrite (see also Ockey 2004: 15-21, on the persistence of the nakleng under conditions demanding enhanced respectability).

Although Pavina finished ahead of Chuwit, more bourgeois Bangkokians professed shock that Chuwit - despite his alleged associations with prostitution came so close to an obviously respectable female candidate. For others, however, care for ordinary people (prachaachon) is less evident in good works than in the moral code of the highly visible underworld; the bandit is but an exaggeration of the culturally intimate persona of the 'good guy', and the only viable alternative is a serene detachment that suggests more of the monastic or even the ideal-typical monarchical model than the politician out to 'seek votes' (haa siang) - or even to buy them. As the Democrats were actively engaged in trying to demonstrate that Thai Rak Thai activists were buying votes on Pavina's behalf (I was assured, during a visit to the party headquarters, that they had collected plenty of evidence), her air of lofty detachment did her no good at all.

In that context, Pavina should perhaps have let her good deeds speak for themselves and instead spoken calmly about policy and ideology. Instead, she unwisely chose to dramatise her self-identification with the poor, dressing herself, in one particularly ill-favoured incident, as a market women bowed down under the weight of a two-pannier basket on a pole. Not surprisingly, this performance backfired. It provoked only derision: she was clearly no peasant woman or market worker herself, and her polite speech and generally upper-class mannerisms made her performance absurdly incongruous. In other words, she transformed her major asset - a reputation for caring - into a terrible liability, seeming to mock the very masses on whose vote she was counting. Her identification with good causes could not overcome the effects of this caricature, a performance that looked more like mockery of those with whom she particularly claimed to empathise. Probably the serious promise of another and very minor candidate, Sumet Tanthanasirikul, to address the persistent problem of relations between the street vendors and the city bureaucracy was a more effective play for working-class votes than Pavina's unsuccessful attempt at identification through self-performance.

The tipping-point, however, was nevertheless almost certainly her failure to participate in another kind of performance. Her non-appearance in the Thammasat University debate suggested either that she was either faint of heart and therefore ill-suited to the rough-and-tumble of political administration or that she considered herself to be above ordinary politics. In either case, her absence was itself a variety of performance, but one that - unlike the deliberate 
projection of modesty that we see in the "disclaimers" of stage musicians and actors (see Bauman 1977: 22) and, I suggest, in some of the candidates' attempts to project themselves as straightforward folks who understood ordinary people's everyday issues - did not even give the appearance of trying to resonate. In the last days of the election, the courtly, restrained, and eminently polite Apirak who had the added advantage of having been both a student leader and later a successful businessman - raced ahead in the polls.

\section{Thai Election Performances: Outcomes and Constraints}

What wins elections does not necessarily consolidate their outcomes. Apirak's time as governor was later to be cut short by a scandal that was probably not significantly of his own making. He had signed documents prepared under his archrival and subsequently prime minister, Samak Sundaravej, that unduly favoured an Austrian bus firm in assigning it a contract to supply the city. When the scandal erupted, Apirak cleverly resigned with a ringing declaration that he wished to serve as an example to other Thai politicians with their corrupt habits, thereby quietly (and so typically) turning the tables on his more raucous and accusatory rivals. Many Thai politicians today regard Apirak as having backed away from the fray, but this is by no means clear. He continued to serve as a parliamentary deputy and as deputy leader of his party right up to the 2014 coup, his reputation relatively unbesmirched by the events that led to Abhisit's use of military force in the suppression of the Red Shirt revolt and subsequent crushing defeat at the polls.

The themes of the 2004 gubernatorial election seem now, in retrospect, remarkably detached from what was shortly to emerge in the streets of Bangkok in the struggle between the two factions known by the respective colours of their shirts, red and yellow. Precisely because of the hiatus that these events created, however, virtually all the issues addressed by the candidates in 2004 remain as potential flashpoints for future contests. That is the state of play at the level of the capital. At a more encompassing level, moreover, the situation is no closer to resolution. The 2011 electoral rejection of Abhisit and his retention as party leader in combination with the continuing prominence of his party and its allies in the capital even (or especially) under military rule, combined with the difficulty of separating egalitarian ideology from authoritarian practices in the country as a whole and at every level of political action, make the prospects of an alignment between capital and nation seem remote. Indeed, the future is fraught with potential dangers as strong forms of localist and even separatist sentiment as well as of class conflict re-emerge in the face of such paralysis at the administrative and symbolic centre. ${ }^{7}$ The overall situation calls for effective

${ }^{7}$ The 'Yellow Shirts' did in fact orchestrate a 'Shut Down Bangkok' movement beginning on 13 January 2014 - an event that helped to precipitate the 2014 coup. But the suppression of political 
rhetoric - the art of persuasion, embodied in capable leaders. It remains to be seen whether, assuming a timely end to military rule, new performances, this time of conciliation and compromise, can tame the involuted tensions between egalitarianism and authoritarianism to the point of opening up more productive political paths for the national polity as a whole.

\section{Acknowledgements}

I would like to express my thanks to Lindsay Lloyd-Smith and two anonymous reviewers for their extremely helpful observations on an earlier draft of this article.

\section{References}

Akin Rabibhadana. 1994. ชีวิต และ จุดจบ ของ สลัม กรุงเทพฯ แห่ง หนึ่ง. (The Life and End of One Bangkok Slum'). Bangkok: Munithii Phumipanyaa.

Askew, Marc. 2008. Performing Political Identity: The Democrat Party in Southern Thailand. Chiang Mai: Silkworm.

Austin, John Langshaw. 1975 [1962]. How to Do Things With Words. $2^{\text {nd }}$ edition, edited by J.O. Urmson and Marina Sbisà. Cambridge, MA: MIT Press.

Aulino, Felicity. 2012. Senses and Sensibilities: The Practice of Care in Everyday Life in Northern Thailand. PhD Dissertation, Department of Anthropology, Harvard University.

Bauman, Richard. 1977. Verbal Art as Performance. Rowley, Mass.: Newbury House.

Connors, Michael. 2003. Democracy and National Identity in Thailand. London: RoutledgeCurzon.

Goffman, Erving. 1959. The Presentation of Self in Everyday Life. Garden City: Doubleday.

Herzfeld, Michael. 1985. The Poetics of Manhood: Contest and Identity in a Cretan Mountain Village. Princeton: Princeton University Press.

Herzfeld, Michael. 2005. Cultural Intimacy: Social Poetics in the Nation-State. $2^{\text {nd }}$ edition. New York: Routledge.

Herzfeld, Michael. 2012. Paradoxes of order in Thai community politics. In Felicity Aulino, Miriam Goheen, and Stanley J. Tambiah, (eds.), Radical Egalitarianism: Local Realities, Global Relations pp. 146-160. New York: Fordham University Press.

Jackson, Peter. 2004. The Thai regime of images. Sojourn: Social Issues in Southeast Asia 19(2), 1-39.

McCargo, Duncan. 2005. Network monarchy and legitimacy crises in Thailand. Pacific Review 18(4), 499-519.

McCargo, Duncan. 2006. Thaksin and the resurgence of violence in the Thai South: network monarchy strikes back? Critical Asian Studies 38(1), 39-71.

Morris, Rosalind. 2004. Intimacy and corruption in Thailand's age of transparency. In Andrew Shryock (ed.), Off Stage/On Display: Intimacy and Ethnography in the Age of Public Culture, pp. 225-243. Stanford: Stanford University Press.

activity that followed hardly suggests the emergence of new strategies for resolving the continuing tensions. 


\section{I34 Michael Herzfeld}

Muehlebach, Andrea. 2009. Complexio oppositorum: notes on the left in neoliberalItaly. Public Culture 21, 495-515.

Nelson, Michael H. 1998. Central Authority and Local Democratization in Thailand. Bangkok: White Lotus.

Ockey, James. 2004. Making Democracy: Leadership, Class, Gender, and Political Participation in Thailand. Honolulu: University of Hawai'i Press.

Sopon Pornchokchai. 1992. Bangkok Slums: Review and Recommendations. Bangkok: School of Urban Community Research and Actions, Agency for Real Estate Affairs. 